\title{
(RE)CONSTRUCTING PERSONAL TEACHING METAPHORS IN A BRAZILIAN TEACHER INITIATION PROJECT
}

\author{
Ana Carolina de Laurentiis Brandão \\ Departamento de Letras, Universidade do Estado de Mato Grosso - UNEMAT (Brazil)
}

\begin{abstract}
This paper explores the (re)construction of pre-service English teachers' personal teaching metaphors as they designed and implemented language teaching materials for the first time. The research participants and I lived alongside each other during the first year of a teacher education project, forming part of a Brazilian government programme called PIBID (Teaching Initiation Scholarship Programme), in which I collaborated as a teacher educator. The programme awards grants to teacher educators, and to pre-service and in-service teachers participating in teacher initiation projects developed by universities in partnership with state schools. The PIBID project, in which the participants of this study were engaged, involved in-service English teachers from two state schools and pre-service teachers designing and implementing language teaching materials with the help of digital resources. To explore the development of student teachers' metaphors, I adopt a narrative inquiry methodology, which considers narrative as both method and way of understanding experience. Considerations about the role of metaphors in teacher education and storied perspectives on identity, knowledge and context also inform this study. The field texts include pre-service teachers' written, spoken and visual narratives of experience gathered over the course of an academic year. The personal teaching metaphors articulated and rearticulated by materials design and implementation experiences encapsulate the pre-service teachers' desire to have a significant impact on pupils' language learning and welfare. They also encapsulate the feelings and challenges concerning the implementation of their images of teaching, and the effect of teaching experiences on their professional identities. Overall, they help the pre-service teachers not only communicate, but also make sense of important stages within their professional identity (re)construction, namely, the imagining, living out and re-imagining of language teaching.
\end{abstract}

Keywords: Narrative inquiry, personal teaching metaphors, professional identity.

\section{Introduction}

Metaphors not only communicate, but also shape our understanding of the world and actions (Lakoff \& Johnson, 1980). Exploring teachers' metaphors is therefore essential for making sense of their beliefs, experiences and professional expectations, as a considerable number of studies have highlighted (e.g., Carter, 1990; Craig, 2018; Kitchen, 2011; Leavy, McSorley, \& Boté, 2007; Pinnegar, Mangelson, Reed, \& Groves, 2011). Furthermore, by becoming aware of their own teaching metaphors, teachers are provided with opportunities to reflect on who they are becoming as professionals.

Metaphors are an important aspect of a teacher's professional identity, which is understood here through Connelly and Clandinin's concept of "stories to live by" (1999, p. 4). In this perspective, "identities have stories, they are narrative constructions that take shape as life unfolds" (p. 95). They are "multiple, evolving, shifting, and contradictory", as teachers experience situations both in their professional and personal lives (Clandinin \& Huber 2005, p. 44). Essential to this definition is the link between identity, knowledge and context (Connelly \& Clandinin, 1999).

Context is seen through the personal and professional knowledge landscapes metaphor, which involves "space, place, and time" and "has a sense of expansiveness and the possibility of being filled with diverse people, things, and events in different relationships" (Clandinin \& Connelly, 1996, p. 24). Knowledge is taken to mean personal practical knowledge, which is "composed of both kinds of knowledge [theoretical and practical], blended by the personal background and characteristics of the teacher, and expressed by her in particular situations" (Clandinin 2013b, p. 67), reflecting both "a person's life story" and "the contexts in which teachers live" (Connelly \& Clandinin, 1999, p. 2). 
Teachers' personal practical knowledge has moral, aesthetic and emotional dimensions, and is informed by metaphors, images of teaching, practical principles, personal philosophies, and narrative unities (Clandinin, 2013b; Connelly \& Clandinin, 1988). Metaphors articulate learning and teaching conceptions, and guide future actions. Images of teaching (and metaphors) are influenced by a teacher's past and are recalled within the present. They reflect the way teachers' imagine teaching spaces and/or themselves in teaching situations. Rules tell teachers what to do in classes. Practical principles concern 'purposes in a deliberate and reflective way' (Connelly \& Clandinin, 1988, p. 64-65). Personal philosophy is 'a way one thinks about oneself in teaching situations' (1988, p. 66). Narrative unity is 'a meaning-giving account, an interpretation, of our history and, as such, provides a way of understanding our experiential knowledge' (1988, p. 75).

By adopting a narrative inquiry methodology (Claninin, 2013a; Clandinin \& Connelly, 2000), this study explores the (re)construction of pre-service English teachers' personal teaching metaphors as they designed and implemented language teaching materials for the first time. My research participants and I lived alongside each other during the first year of a teacher education project, forming part of a Brazilian government programme called PIBID (Teaching Initiation Scholarship Programme), in which I collaborated as a teacher educator. The programme is sponsored by CAPES (Coordination for the Improvement of Higher Education Personnel), awarding grants to teacher educators, and to pre-service and in-service teachers participating in teacher initiation projects developed by universities in partnership with state schools. Its main aims are to integrate schools and teaching degree programmes, and to improve the quality of education at state schools.

This paper is organized in three sections. I begin by outlining my methodological approach. Then, I discuss the participants' metaphors derived from their process of designing and implementing language teaching materials. Finally, I present some thoughts that emerged from the discussion and the wider implications of this study.

\section{Design}

This study takes the form of a narrative inquiry, a research methodology that analyses experience as a storied phenomenon (Clandinin, 2013a; Clandinin \& Connelly, 2000). Analysis involves the reconstruction of participants' experiences, situating field texts (the term for data in this narrative approach) within the three-dimensional inquiry space: temporality, sociality and place (Clandinin 2013a; Clandinin \& Connelly 2000). Temporality refers to the past, present and future of the experience. Sociality refers to personal and social conditions. Place refers to the influence of the location. The field texts include written, spoken and visual narratives, taking the form of written journals, drawings and recorded conversations gathered over the course of an academic year.

Narrative inquiry's emphasis on particular people and circumstances demands a reduced number of participants, six pre-service English teachers in this case. Here, I discuss the metaphors derived from language teaching materials design and implementation experiences of three of them. They gave themselves the pseudonyms Alice, Carla and Marcela. When field texts began to be gathered, Alice was 50 years old, Carla was 24 years old and Marcela was 18 years old. They were in the second year of her undergraduate Portuguese-English language teaching degree.

The PIBID project that my participants and I were engaged in involved in-service and pre-service teachers designing and implementing English reading activities with the help of digital resources. The PCN (National Curriculum Parameters) (Brasil, 1998) and the OCEM (Curriculum Guidelines for High School) (Brasil, 2006) served as guiding educational documents. This study follows the first year of the project. I designed the project's proposal and collaborated as a teacher educator.

\section{Discussion}

Materials design and implementation helped the pre-service English teachers articulate and rearticulate their personal teaching metaphors. Such metaphors informed and shaped the pre-services' stories to live by (Connelly \& Clandinin, 1999), that is, their professional identities by weaving together diverse aspects of their personal practical knowledge, such as: images of teaching, rules, practical principles, personal philosophies and narrative unities (Clandinin, 2103b; Connelly \& Clandinin, 1988). The personal teaching metaphors articulated and rearticulated by materials design and implementation experiences encapsulated the pre-service teachers' desire to have a significant impact on pupils' language learning and welfare. They also encapsulated the feelings and challenges concerning the implementation of their images of teaching, and the effect of teaching experiences on their professional identities. Overall, they helped the pre-service teachers not only communicate, but also make sense of important stages 
within their professional identity (re)construction, namely, the imagining, living out and re-imagining of English teaching.

Some pre-service teachers used different metaphors for each stage, while others continued to embellish a particular metaphor throughout. Alice, for example, used the invisible/visible English teacher metaphor to make sense of English teaching and refer to the type of teacher she wanted to be (e.g., a proficient teacher who could build a rapport with pupils and break up the routine). The metaphor then represented her attempts to live out her imagined identity. By the end of her materials design and implementation experiences, she incorporated other features to her metaphor (e.g., the role of schools in the search for visibility and the understanding of this process as never ending), as she re-imagined English teaching.

Carla used the image of the dream English classroom (where teachers simply transferred content and pupils behaved) to account for how she imagined English teaching. This metaphor also articulated her struggles to live up to the dream English teacher in the reality of the school where she would implement her materials. After failed attempts to implement her materials, she realized that such an image could no longer shape her goals as a teacher. As Carla re-imagined English teaching by identifying areas for improvement (e.g., how to communicate with pupils and control the class), the dream English classroom began to evaporate.

Marcela imagined English teaching through her metaphor of the teacher showing that English is not rocket science (e.g., by being innovative and caring). Nevertheless, she herself doubted her ability to implement this image due to her language level. As she lived out the profession, she used this metaphor to make sense of her own teacher development: Marcela discovered that teaching English was not rocket science. For example, she realised that by studying English more independently and developing themes in classes, her pupils would not find learning English rocket science.

This study highlights the link between materials development and the (re)articulation of personal teaching metaphors. In particular, it sheds light on how new metaphors, or interpretations attributed to existing ones, emerge as teachers re-examine conceptions, and confront the uncertain throughout the process. While imagining teaching situations, writing and trying out their own activities, teachers get to identify, reflect on and rethink their personal teaching metaphors. Furthermore, this narrative inquiry identifies different categories of metaphors, which account for teacher identity (re)construction in its early stages. There are metaphors capturing how pre-service teachers imagine the profession (articulating images of teaching and professional expectations), live out the profession (articulating the negotiation of their imagined teacher identities), and re-imagine the profession (articulating the effect of teaching experiences on them). This awareness, in turn, reinforces the importance of exploring metaphors in second language teaching education practice and research as a means of understanding how teachers experience teacher preparation and the profession, as well as of tracing and fostering professional development.

\section{Conclusion}

Narrative inquiry is shaped by "particularity and incompleteness" and thus "leads less to generalizations and certainties" (Clandinin, 2013a, p. 52). It values "a particular experience, in a particular setting, involving particular people" (Pinnegar \& Daynes, 2007, p. 21), and aims to "understand rather than control and predict the human world" (p. 30). The methodology's strength lies in "understanding the complexity of the individual, local and particular", providing "a surer base for our relationships and interactions with other humans" (Pinnegar \& Daynes, 2007, p. 30).

In exploring the metaphors that particular pre-service English teachers derive from their experiences of designing and implementing materials in particular settings, this narrative inquiry is insightful for both second language teacher education practice and research. It illustrates teacher identity formation in its early stages, shedding light on how pre-service teachers imagine, live out and re-imagine the profession. This in turn can inform second language teacher education curriculum. For example, teacher educators may consider the pre-service teacher identity formation stages explored in this study (imagining, negotiating and re-imagining stories of teaching English) when designing proposals in their own programmes. Second language teacher education researchers, meanwhile, may adapt these stages in order to study teacher development in other contexts. 


\section{References}

Brasil, Ministério da Educação (1998). Secretaria de Educação Fundamental. Parâmetros curriculares nacionais - Língua estrangeira [National curriculum parameters - Foreign language]. Brasília: $\mathrm{MEC} / \mathrm{SEF}$.

Brasil, Ministério da Educação (2006). Secretaria de Educação Básica. Orientações curriculares para o ensino médio: Linguagens, códigos e suas tecnologias [Curriculum guidelines for high school: Languages, codes and their technologies]. Brasília: MEC/SEB.

Carter, K. (1990). Meaning and metaphor: Case knowledge in teaching. Theory into Practice, 29(2), 109-115.

Clandinin, D. J. (2013a). Engaging in narrative inquiry. Walnut Creek, CA: Left Coast Press.

Clandinin, D. J. (2013b). Personal practical knowledge: A study of teachers' classroom images. In C. J. Craig, P. C. Meijer \& J. Broeckmans (Eds.), From teacher thinking to teachers and teaching: The evolution of a research community (pp. 67-95). Bingley, UK: Emerald.

Clandinin, D. J., \& Connelly, F. M. (2000). Narrative inquiry: Experience and story in qualitative research. San Francisco, CA: Jossey-Bass.

Clandinin, D. J., \& Connelly, F. M. (1996). Teachers' professional knowledge landscapes: Teacher stories - stories of teachers - school stories - stories of schools. Educational Researcher, 25(3), 24-30.

Clandinin, D. J., \& Huber, M. (2005). Shifting stories to live by: Interweaving the personal and professional in teachers' lives. In D. Beijaard, P. C. Meijer, G. Morine-Dershimer \& H. Tillema (Eds.), Teacher professional development in changing conditions (pp. 43-59). Dordrecht, The Netherlands: Springer.

Connelly, F. M., \& Clandinin, D. J. (Eds.). (1999). Shaping a professional identity: Stories of educational practice. New York: Teachers College Press.

Connelly, F. M., \& Clandinin, D. J. (1988). Teachers as curriculum planners: Narratives of experience. New York: Teachers' College Press.

Craig, C. J. (2018). Metaphors of knowing, doing and being: Capturing experience in teaching and teacher education. Teaching and Teacher Education, 69, 300-311.

Kitchen, J. (2011). Imagining and re-imagining our students and ourselves: Using metaphor to story the experiences of teacher candidates and teacher educators. In J. Kitchen, D. C. Parker, \& D. Pushor (Eds.), Narrative inquiries into curriculum making in teacher education (pp. 109-128). Bingley, UK: Emerald.

Leavy, A. M., McSorley, F. A., \& Boté, L. A. (2007). An examination of what metaphor construction reveals about the evolution of preservice teachers' beliefs about teaching and learning. Teaching and teacher education, 23(7), 1217-1233

Pinnegar, S., \& Daynes, J. G. (2007). Locating narrative inquiry historically: Thematics in the turn to narrative. In D. J. Clandinin (Ed.), Handbook of narrative inquiry: Mapping a methodology (pp. 3-34). Thousand Oaks, CA: Sage.

Pinnegar, S., Mangelson, J., Reed, M., \& Groves, S. (2011). Exploring preservice teachers' metaphor plotlines. Teaching and Teacher Education, 27(3), 639-647. 